\title{
Lymphocytic hypophysitis: non-invasive diagnosis and treatment by high dose methylprednisolone pulse therapy?
}

\author{
Rudolf A Kristof, Dirk Van Roost, Dietrich Klingmüller, Wolfram Springer, \\ Johannes Schramm
}

\begin{abstract}
Criteria for the non-invasive diagnosis of lymphocytic hypophysitis (LyHy) and the results of the first prospective trial of high dose methylprednisolone pulse therapy (HDMPT) in nine patients are presented. In three patients, the diagnosis was established histologically, and in the others by clinical and endocrinological assessment, MRI, CSF examination, and measurement of thyroglobulin autoantibody concentration. After HDMPT, adenopituitary function improved in four of the nine patients and diabetes insipidus ceased or improved in all four concerned patients. The MRI findings improved in seven patients. LyHy has to be considered in the differential diagnosis of sellar lesions. The presumptive non-invasive diagnosis of LyHy seems possible in a high proportion of patients. HDMPT may result in the improvement of clinical, endocrinological, and MRI findings.

(F Neurol Neurosurg Psychiatry 1999;67:398-402)
\end{abstract}

Keywords: lymphocytic hypophysitis; high dose methylprednisolone pulse therapy

Department of

Neurosurgery,

University of Bonn,

Germany

R A Kristof

D Van Roost

J Schramm

Institute of

Biochemistry,

Neuroendocrinology,

University of Bonn,

Germany

D Klingmüller

W Springer

Correspondence to: Dr Rudolf A Kristof,

Neurochirurgische

Universitätsklinik,

Sigmund-Freud-Strasse 25

D-53105 Bonn, Germany.

Telephone 0049228287

6521; fax 0049228287

6772 .

Received 15 May 1998 and in final form

9 February 1999

Accepted 16 February 1999

Lymphocytic hypophysitis (LyHy) is a rare chronic inflammatory disease with little known natural history, ${ }^{1-7}$ usually diagnosed unexpectedly at surgery for presumptive pituitary adenoma. ${ }^{1589}$ Experience in the treatment of LyHy is scarce. ${ }^{3}{ }^{10-12}$

Non-invasive diagnostic criteria and results of standardised HDMPT are presented.

\section{Patients and methods}

All patients with LyHy (mean age 41 years, seven women) diagnosed at our institution are reported on. Adenohypophyseal function was dynamically assessed as described by Thorner et $a .^{13}$ Neurohypophyseal function was assessed as described by Reeves and Andreoli. ${ }^{14}$ Evaluation of the sellar region by MRI was carried out as described by Elster. ${ }^{15}$ In the six patients not operated on, CSF was evaluated by white cell count, cytology, global protein content, and neurotropic virus serology (herpes simplex, varicella zoster, mumps). The thy- roglobulin autoantibody concentration was measured in four patients. In three patients, LyHy was diagnosed histologically. In the others, differential diagnosis was considered for tuberculosis, sarcoidosis, and syphilis by clinical, laboratory (tuberculin test, angiotensin I converting enzyme measurement, treponema pallidum haemaglutination test), and chest radiograhy evaluation.

The high dose short lasting methylprednisolone administration aimed at minimising the side effects of chronic corticosteroid therapy and at differentiating therapeutic effects from longterm natural course of LyHy. HDMPT consisted of $120 \mathrm{mg}$ methylprednisolone daily for 2 weeks, followed by a dose reduction to $80,60,40$, and $20 \mathrm{mg}$ daily for 1 week each. Each patient received one course of HDMPT.

Results were assessed by endocrinology and MRI as presented above, at 3, 6, and 12 month intervals thereafter. The average follow up amounted to 29 (19-38) months.

Literature research was done using the Medline program and the key word hypophysitis.

\section{Results}

The patient's details and courses of disease are listed in the table.

Two of the three patients operated on were only biopsied because the intraoperative findings were inconsistent with an adenoma. The third was mimicking an adenoma and was completely resected. LyHy represented 1.1\% of all sellar pathologies sampled by a transsphenoidal approach.

Disease onset was sudden in five (four diabetes insipidus, one local mass effect) and insidious in four (adenopituitary impairment) patients.

The amount of daily urinary excretion in the patients with diabetes insipidus varied between 6 and 12 litres. All patients presented with adenopituitary impairment.

Evaluation of CSF in six patients disclosed a raised cell count of 72 (SD 64) cells $/ \mathrm{mm}^{3}$. The global protein content of $\mathrm{CSF}$ (47 (SD 18) $\mathrm{mg} / \mathrm{dl}$ ), cytology (lymphomonocytic cells), and neurotropic virus serology were normal. 
Findings and courses of nine patients with lymphocytic hypophysitis treated by high dose methylprednisolone pulse therapy

\begin{tabular}{|c|c|c|c|c|c|}
\hline Age, sex & Clinical presentation & Laboratory findings & $M R I$ & Biopsy & Follow up \\
\hline $\begin{array}{l}\text { Case } 1 \\
23 \mathrm{y} \\
\mathrm{M}\end{array}$ & $\begin{array}{l}\text { Slowly progressive } \\
\text { hypopituitarism over } \\
6 \text { years }\end{array}$ & $\begin{array}{l}\text { Impaired pituitary functions: } \\
\mathrm{C}, \mathrm{G}, \mathrm{S}, \mathrm{L}, \mathrm{T}\end{array}$ & $\begin{array}{l}\text { Global symmetric enlargement of } \\
\text { anterior pituitary lobe with slight } \\
\text { suprasellar extension and marked } \\
\text { homogeneous contrast enhancement. } \\
\text { Thickened, enhancing sellar } \\
\text { diaphragm. Thickened and markedly } \\
\text { enhancing pituitary stalk }\end{array}$ & $\begin{array}{l}\text { Thickened sellar } \\
\text { endosteum. Whitish, } \\
\text { firm sellar content }\end{array}$ & $\begin{array}{l}38 \text { months. No improvement of } \\
\text { pituitary function. Slight } \\
\text { shrinkage of enlarged sellar } \\
\text { content and pituitary stalk }\end{array}$ \\
\hline $\begin{array}{l}\text { Case } 2 \\
29 \mathrm{y}, \mathrm{F}\end{array}$ & $\begin{array}{l}\text { Headache and } \\
\text { chiasm compression } \\
\text { since } 4 \text { months, } \\
\text { starting in the last } \\
\text { trimester of } \\
\text { pregnancy }\end{array}$ & $\begin{array}{l}\text { Impaired pituitary functions: } \\
\mathrm{C}, \mathrm{G}, \mathrm{S}, \mathrm{L}\end{array}$ & $\begin{array}{l}\text { Global symmetric enlargement of } \\
\text { anterior pituitary lobe with } \\
\text { suprasellar extension and marked } \\
\text { homogeneous contrast enhancement. } \\
\text { Thickened and markedly enhancing } \\
\text { pituitary stalk }\end{array}$ & $\begin{array}{l}\text { Thickened sellar } \\
\text { endosteum. Whitish } \\
\text { firm sellar content }\end{array}$ & $\begin{array}{l}36 \text { months. Normalisation of } G \\
\text { and } S \text { pituitary function, } C \text { and } \\
\text { L impairment unchanged. } \\
\text { Shrinkage of sellar content } \\
\text { nearly to an empty sella, } \\
\text { shrinkage of thickened pituitary } \\
\text { stalk }\end{array}$ \\
\hline $\begin{array}{l}\text { Case } 3 \\
36 y, F\end{array}$ & $\begin{array}{l}\text { Oligomenorrhoea } \\
\text { for } 6 \text { months }\end{array}$ & $\begin{array}{l}\text { Impaired pituitary functions: } \\
\mathrm{G}, \mathrm{S}, \mathrm{L}\end{array}$ & $\begin{array}{l}\text { Slightly asymmetric enlargement of } \\
\text { anterior pituitary lobe with } \\
\text { suprasellar extension and marked } \\
\text { homogeneous contrast enhancement. } \\
\text { Pituitary stalk of normal appearance }\end{array}$ & $\begin{array}{l}\text { Reddish inflammatory } \\
\text { nodule of firm } \\
\text { consistence, delineable } \\
\text { from the pituitary. } \\
\text { Complete removal. }\end{array}$ & $\begin{array}{l}24 \text { months. Persistent } \\
\text { impairment of G, S, L function, } \\
\text { postoperatively persistent DI. } \\
\text { MRI not evaluable because of } \\
\text { extensive surgery }\end{array}$ \\
\hline $\begin{array}{l}\text { Case } 4 \\
44 \mathrm{y}, \mathrm{F}\end{array}$ & $\begin{array}{l}\text { Sudden onset of } \\
\text { diabetes insipidus } \\
\text { (DI) } 1 \text { month } \\
\text { previously }\end{array}$ & $\begin{array}{l}\text { Impaired pituitary functions: } \\
\text { S, DI } \\
\text { CSF: } 78 \text { lympho-monocytic } \\
\text { cells } / \mathrm{mm}^{3}, 28 \mathrm{mg} / \mathrm{dl} \text { global } \\
\text { protein content; virus serology } \\
\text { negative. }\end{array}$ & $\begin{array}{l}\text { Global symmetric enlargement of } \\
\text { anterior pituitary lobe with } \\
\text { suprasellar extension, ring-like } \\
\text { enhancement of pituitary. Thickened } \\
\text { and markedly enhancing pituitary } \\
\text { stalk }\end{array}$ & Not done & $\begin{array}{l}42 \text { months. DI ceased, } \\
\text { persistent impairment of S } \\
\text { function. Shrinkage of the sellar } \\
\text { content, pituitary stalk still } \\
\text { somewhat enlarged }\end{array}$ \\
\hline $\begin{array}{l}\text { Case } 5 \\
40 \mathrm{y}, \mathrm{F}\end{array}$ & $\begin{array}{l}\text { Progressive } \\
\text { hypopituitarism over } \\
6 \text { months }\end{array}$ & $\begin{array}{l}\text { Impaired pituitary functions: } \\
\mathrm{C}, \mathrm{T}, \mathrm{G}, \mathrm{L} \text {. CSF: } 48 \\
\text { lymphomonocytic cells } / \mathrm{mm}^{3} \text {, } \\
38 \mathrm{mg} / \mathrm{dl} \text { global protein content; } \\
\text { virus serology negative. }\end{array}$ & $\begin{array}{l}\text { Global symmetric enlargement of } \\
\text { anterior pituitary lobe with slight } \\
\text { suprasellar extension and marked } \\
\text { homogeneous contrast enhancement. } \\
\text { Pituitary stalk of normal appearance }\end{array}$ & Not done & $\begin{array}{l}36 \text { months. Normalisation of } \mathrm{G} \\
\text { and improvement of } \mathrm{T} \\
\text { impairment, C and L } \\
\text { impairment unchanged. } \\
\text { Shrinkage of sellar content }\end{array}$ \\
\hline $\begin{array}{l}\text { Case } 6 \\
42 \mathrm{y}, \mathrm{F}\end{array}$ & $\begin{array}{l}\text { Sudden onset of DI } \\
1.5 \text { years previously }\end{array}$ & $\begin{array}{l}\text { Impaired pituitary functions: } \\
\mathrm{C}, \mathrm{S}, \mathrm{DI} \text {. CSF: } 30 \\
\text { lymphomonocytic cells } / \mathrm{mm}^{3} \text {, } \\
31 \mathrm{mg} / \mathrm{dl} \text { global protein content; } \\
\text { virus serology negative. } \\
\text { Thyroglobulin autoantibody } \\
\text { concentration not risen. }\end{array}$ & $\begin{array}{l}\text { Sellar content of normal extent, } \\
\text { posterior lobe not delineable. } \\
\text { Homogeneous marked contrast } \\
\text { enhancement of the sellar content. } \\
\text { Pituitary stalk slightly thickened and } \\
\text { markedly enhancing }\end{array}$ & Not done & $\begin{array}{l}27 \text { months. Normalisation of C } \\
\text { function. Improvement of DI } \\
\text { and S impairment. Shrinkage of } \\
\text { the thickened pituitary stalk }\end{array}$ \\
\hline $\begin{array}{l}\text { Case } 7 \\
30 y, M\end{array}$ & $\begin{array}{l}\text { Sudden onset of DI } \\
2 \text { months previously }\end{array}$ & $\begin{array}{l}\text { Impaired pituitary functions: } \\
\text { C, DI. CSF: } 33 \\
\text { lymphomonocytic cells } / \mathrm{mm}^{3}, 54 \\
\text { mg/dl global protein content; } \\
\text { virus serology negative. } \\
\text { Thyroglobulin autoantibody } \\
\text { concentration not risen. }\end{array}$ & $\begin{array}{l}\text { Slight symmetric enlargement of } \\
\text { sellar content with prominence of the } \\
\text { posterior lobe. Marked and } \\
\text { homogeneous contrast enhancement } \\
\text { of the sellar content. Pituitary stalk } \\
\text { of normal appearence }\end{array}$ & Not done & $\begin{array}{l}19 \text { months. DI ceased, } \\
\text { persistent slight impairment of } \\
\text { C function. No change of sellar } \\
\text { content }\end{array}$ \\
\hline $\begin{array}{l}\text { Case } 8 \\
62 \mathrm{y}, \mathrm{F}\end{array}$ & $\begin{array}{l}\text { Sudden onset of DI } \\
2 \text { months previously }\end{array}$ & $\begin{array}{l}\text { Impaired pituitary functions: } \\
\mathrm{C}, \mathrm{G}, \mathrm{S}, \mathrm{DI} \text {. CSF: } 198 \\
\text { lympho-monocytic cells } / \mathrm{mm}^{3} \text {, } \\
56 \mathrm{mg} / \mathrm{dl} \text { global protein content, } \\
\text { virus serology negative. } \\
\text { Thyroglobulin autoantibody } \\
\text { concentration not risen. }\end{array}$ & $\begin{array}{l}\text { Sellar content of normal extent, } \\
\text { posterior lobe not delineable. } \\
\text { Marked and homogeneous } \\
\text { enhancement of sellar content. } \\
\text { Pituitary stalk thickened and strongly } \\
\text { enhancing }\end{array}$ & Not done & $\begin{array}{l}19 \text { months. DI ceased, G } \\
\text { normalised, S improved, } \\
\text { persistent impairment of C } \\
\text { function. Shrinkage of pituitary } \\
\text { stalk }\end{array}$ \\
\hline $\begin{array}{l}\text { Case } 9 \\
62 \mathrm{y}, \mathrm{F}\end{array}$ & $\begin{array}{l}\text { Progredient decrease } \\
\text { of performance over } \\
1.5 \text { years }\end{array}$ & $\begin{array}{l}\text { Impaired pituitary functions: } \\
\text { S. CSF: } 45 \text { lympho-monocytic } \\
\text { cells/mm } 3 \mathrm{~mm}^{3}, 75 \mathrm{mg} / \mathrm{dl} \text { global } \\
\text { protein content; virus serology } \\
\text { negative. Thyroglobulin } \\
\text { autoantibody concentration } \\
\text { markedly risen }(1935.6 \mathrm{U} / \mathrm{ml}) \text {. }\end{array}$ & $\begin{array}{l}\text { Global symmetric enlargement of the } \\
\text { anterior pituitary lobe with } \\
\text { suprasellar extension and marked } \\
\text { homogeneous contrast enhancement. } \\
\text { Thickened and markedly enhancing } \\
\text { pituitary stalk }\end{array}$ & Not done & $\begin{array}{l}19 \text { months. Persistent } \\
\text { impairment of S function. } \\
\text { Thyroglobulin autoantibody } \\
\text { concentration normalised }(<40 \\
\text { U/ml). Slight shrinkage of sellar } \\
\text { content and of pituitary stalk }\end{array}$ \\
\hline
\end{tabular}

$\mathrm{C}=$ Corticotroph; $\mathrm{T}=$ thyreotroph; $\mathrm{G}=$ gonadotroph; $\mathrm{S}=$ somatotroph; $\mathrm{L}=$ lactotroph.

On plain T1 weighted MRI, the sellar content was slightly to moderately and roughly symmetrically enlarged with suprasellar expansion in seven patients. The posterior lobe was not discernible in two patients. On postcontrast T1 weighted images, the sellar content enhanced strongly and homogeneously in eight patients, and showed a hypointense area in one case. The pituitary stalk was thickened and strongly enhancing in five patients. The presence of a thickened pituitary stalk and the occurrence of diabetes insipidus were not invariably linked.

HDMPT was well tolerated by all patients (a transient rash and an oral mycosis occurred once each). Diabetes insipidus resolved in three patients and improved to the degree of a lesser need of desmopressin in one. In patient 3, diabetes insipidus developed after surgery and was not influenced by HDMPT. Adenopi- tuitary function improved in four out of nine patients and remained unchanged in the others (including patient 3). Hormone replacement could be reduced or stopped in four of seven patients.

Shrinkage of the sellar mass or pituitary stalk was seen on MRI in seven patients (patient 3 not assessable), varying from a slight degree of shrinkage to nearly an empty sella (figure).

\section{Discussion}

The histological characteristics of LyHy are well established. ${ }^{15891617}$ Its aetiology is unclear, with some evidence for an autoimmunological, ${ }^{15}$ possibly virus induced origin. $^{4} 7$

\section{DIAGNOSIS}

Up to $199043,{ }^{5}$ and up to 199572 additional patients were reported on (authors' review). Probably due to a higher awareness, modern 

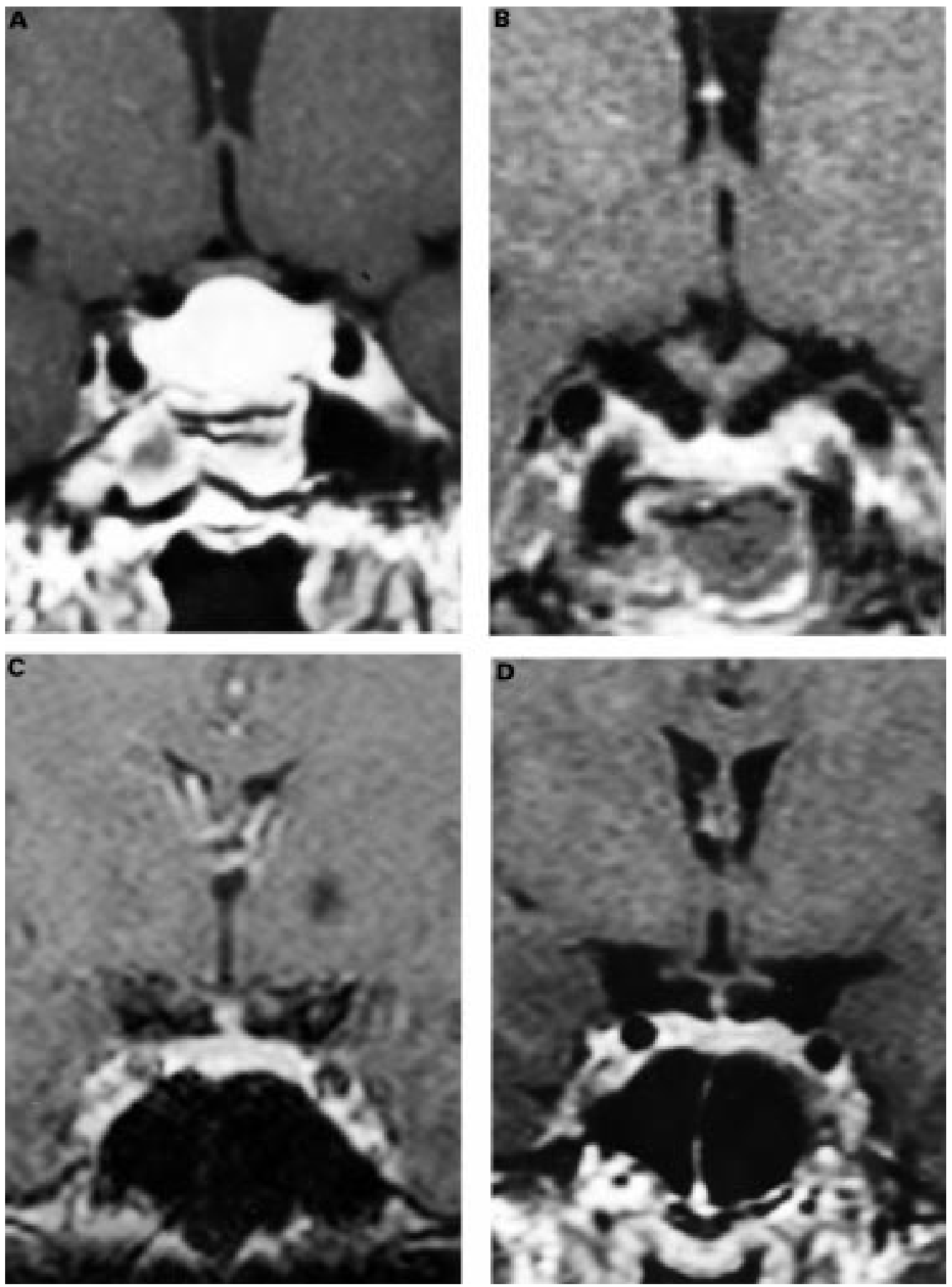

Coronal contrast enhanced MRI of lymphocytic hypophysitis before and after HDMPT: marked shrinkage of the sellar content and slight shrinkage of the pituitary stalk after HDMPT in patient $2(A, B)$; slight shrinkage of the sellar content and of the pituitary stalk after HDMPT in patient $6(C, D)$.

endocrinology, and neuroimaging, LyHy is diagnosed with increasing frequency, and there is an apparent change in its presentation.

The preponderance of females $\left(98 \%{ }^{5}-79 \%\right)$, often with a peripartum onset $\left(62 \%{ }^{5}-47 \%\right)$ and the sudden onset of diabetes insipidus ("exceptional" $-31 \%$ ) are clinical hallmarks of LyHy. However, the present series suggests that the involvement of the neuropituitary on MRI and diabetes insipidus are not invariably linked. Other manifestations such as headache, chiasm compression, and diplopia (44\%, 26\%, and $6 \%$ respectively) lack specificity.

The adenopituitary impairment was disproportionate to the often small extent of the pituitary mass on MRI in the present series. The impairment $\left(77 \%{ }^{5}-47 \%\right)$ seems to develop earlier in LyHy and more often concerns corticotrophic and thyrotrophic functions (56\% and $40 \%$ ) than in pituitary adenoma, in which the somatotrophic and gonadotrophic functions are usually the first to be impaired. ${ }^{161920}$

The association with other autoimmunological diseases in $30 \%$ of the patients, usually a thyroiditis, may be a diagnostic hint for LyHy. ${ }^{5}$

White cell count in the CSF showed a significantly $(\alpha=0.05)$ higher lymphomonocytic pleocytosis in LyHy (72 (SD 64) cells $/ \mathrm{mm}^{3}$ ), compared with seven patients with 
histologically confirmed pituitary adenoma (14 (SD 11) cells $/ \mathrm{mm}^{3}$ ). Together with the absence of antiviral antibodies and of clinical meningitis, this slight pleocytosis in LyHy is likely to be an aseptic meningeal reaction to pituitary inflammation.

The symmetric enlargement of sellar content $(66 \%)$ seen on MRI with thickening of the pituitary stalk (56\%), both homogeneously enhancing, were confirmed in 51 patients reviewed from the literature (published 1991 to 1997 ) in $51 \%$ of the patients. Asymmetry of the enlarged sellar content (18\%), signal alterations on native $\mathrm{T} 1$ weighted $(9 \%)$ or inhomogeneous contrast enhancement $(12 \%)$, cavernous sinus and hypothalamus involvement $(12 \%)$, empty sella $(9 \%)$, and no pathological findings $(9 \%)$ have also been described.

Although no single above feature is pathognomonic of LyHy, their simultaneous presence will confer a higher amount of diagnostic reliability. However, some uncertainty will always persist without histological confirmation of the diagnosis.

Differential diagnosis against common sellar tumours, ${ }^{5}$ such as pituitary adenomas, craniopharyngiomas, and meningiomas, will focus on the frequent peripartal occurrence, the marked adenopituitary impairment, and frequent presence of diabetes insipidus, the presence of other autoimmunological diseases, and on the common MRI appearance of LyHy. Differential diagnosis to common sellar inflammations, ${ }^{5}$ such as tuberculosis, sarcoidosis, and syphilis, will focus on medical history (usually chronic and previously known diseases), laboratory findings (tuberculin test and antigene polymerase chain reaction in CSF for tuberculosis, angiotensin-I-converting enzyme in plasma for sarcoidosis, treponema pallidum hemagglutination test for syphilis), chest radiography (tuberculosis and sarcoidosis), and less upon MRI. In very rare tumours such as histocytosis $\mathrm{X}$ and inflammations such as primary granulomatous hypophysitis, differential diagnosis is virtually impossible to establish except by histology. It has been suggested that LyHy and primary granulomatous hypophysitis may be part of the same disease range. ${ }^{217}$

\section{TREATMENT}

LyHy may become worse due to progressive pituitary insufficiency, ${ }^{159}$ but also may improve spontaneously. ${ }^{452122}$ Adequate hormone replacement therapy is crucial.

Although LyHy is a chronic inflammatory process, probably of autoimmune aetiology, anti-inflammatory corticosteroid treatment has not been systematically used so far. Thirteen patients in the literature, ${ }^{369-12} 16^{16-1823-25}$ nine of them preoperatively, were treated with a mean daily dose of $27.5 \mathrm{mg}$ methylprednisolone equivalent (range 13 to $41 \mathrm{mg}$, not detailed in three patients) for a mean time of 4.75 months (range 5 days to 19 months). Lasting improvements (endocrinological and neuroradiological) occurred in $15 \%$ and transient improvements (also neurological ones) in $62 \%$ of the cases. Relapse of symptoms occurred days to a few months after discontinuation of corticosteroid therapy.

The nine patients of this series were treated in a standardised manner by HDMPT. Improvement of adenopituitary function was found in $44 \%$ of the patients and was more favourable in cases with short standing disease (6 months or less). In three patients the improvements occurred within 6 weeks and in the fourth within 6 months after HDMPT. Diabetes insipidus ceased in three and improved in one of four patients during HDMPT. Normalisation or improvement of MRI findings occurred in $88 \%$ of the patients, in seven within 6 weeks and in the eight within 6 months after HDMPT. Here, the duration of the disease seemed to be of no importance. Because of the close temporal relation, endocrinological and MRI improvements are most likely attributed to HDMPT and not to a favourable natural course of LyHy which eventually would be expected to occur over months or years. ${ }^{451218-22{ }^{26}}$ Neither a relapse of the disease, nor further (spontaneous) improvement, were found in this series.

It remains doubtful whether the results of HDMPT are definitive because follow up is relatively short. Nevertheless, they compare favourably with those reported in the literature and also with the natural course of the disease, the most probable explanation being the regimen of drug application used in this series. On the other hand, complete recovery of the pituitary was achieved in none of our patients. This might be due to a suboptimal regimen of drug application, but also to an already irreversible destruction of the pituitary by LyHy. ${ }^{11}$

Whereas surgery for mass effect in LyHy invariably led to rapid relief of neurological symptoms, endocrinological improvement was seldom reported. ${ }^{5}$ In some patients, however, surgery led to worsening of pituitary function or was followed by recurrence of symptoms (patient 3). ${ }^{2591726}$ Usually the intraoperative findings differ from those of a pituitary adenoma. Quick frozen sections will help to clarify any doubts. In some patients, inflammation may intraoperatively mimick a pituitary adenoma (patient 3). ${ }^{163}$ To avoid potential worsening of the pituitary function, surgery should be kept limited when LyHy is suspected intraoperatively and HDMPT should be considered.

In view of recent experience, the presumptive diagnosis of LyHy may be established by conservative evaluation in a high proportion of patients. The presented results suggest a trial of HDMPT under close monitoring of endocrinological, neuro-ophthalmological, and MRI findings. Follow up has to be at short intervals to identify a possible relapse in time. Indications for surgery are the presence of gross chiasm compression, ineffectiveness of corticosteroid therapy, and the impossibility of establishing the diagnosis of LyHy with sufficient certainty by conservative evaluation. 
1 Cosman F, Post KD, Holub DA, et al. Lymphocytic hypophysitis. Report of 3 new cases and review of the

2 Honegger J, Fahlbusch R, Bornemann A, et al. Lymphocytic and granulomatous hypophysitis: experience with nine cases. Neurosurgery 1997;40:713-23.

3 Nishioka H, Ito $\mathrm{H}$, Miki $\mathrm{T}$, et al. A case of lymphocytic hypophysitis with massive fibrosis and the role of surgical intervention. Surg Neurol 1994;42:74-8

4 Ozawa Y, Shishiba OY. Recovery from lymphocytic hypophysitis associated with painless thyroiditis: clinical implications of circulating antipituitary antibodies. Acto Endocrinol 1993;28:493-8.

5 Parent AD. Lymphoid hypophysitis. In: Wilkins RH, Rengachary SS, eds. Neurosurgery update II. New York: McGrawHill, 1992:3-8.

6 Pestell RG, Best JD, Alford FP. Lymphocytic hypophysitis. The clinical spectrum of the disorder and evidence for an autoimmune pathogenesis. Clin Endocrinol 1990;33: autoimm $457-66$.

7 Yoon JW, Chol DS, Liang HX, et al. Induction of an organspecific autoimmune disease, lymphocytic hypophysitis, in hamsters by recombinant rubella virus glycoprotein and prevention of disease by neonatal thymectomy. $f$ Viro

8 Supler ML, Mickle JP. Lymphocytic hypophysitis: report of a case in a man with cavernous sinus involvement. Surg Neurol 1992;37:472-76.

9 Thodou E, Asa SL, Kontogeorgos G, et al. Clinical case seminar: lymphocytic hypophysitis: clinicopathological findings. F Clin Endocrinol Metab 1995;80:2302-11.

10 Beressi N, Cohen R, Beressi JP, et al. Pseudotumoral lymphocytic hypophysitis successfully treated by corticosteroid alone: first case report. Neurosurgery 1994:35: 505-8.

11 Reusch JEB, Kleinschmidt-DeMasters KB, Lillehei KO, et al. Preoperative diagnosis of lymphocytic hypophysitis (adenohypophysitis) unresponsive to short course dexamethasone: case report. Neurosurgery 1992;30: 268-72.

12 Stelmach M, O'Day J. Rapid change in visual fields associated with suprastellar lymphocytic hypophysitis. $\mathcal{F}$ Clin Neuroopthalmol 1991;11:19-24.
13 Thorner MO, Vance ML, Horvath E, et al. The anterior pituitary: dynamic tests of pituitary function. In: Wilson D, Foster DW, eds. Williams textbook of endocrinology.

14 Reeves WB, Andreoli TE. The posterior pituitary and water metabolism: central diabetes insipidus, In: Wilson JD, Foster DV, eds. Williams textbook of endocrinology. Philadelphia: WB Saunders, 1992;8:333-8.

15 Elster AD. Modern imaging of the pituitary. Radiology 1993; 187:1-14

16 Ahmed SR, Aiello DP, Page R, et al. Necrotizing infundibulohypophysitis: a unique syndrome of diabetes insipidus and hypopituitarism. F Clin Endocrinol Metab 1993;76:1499-504.

17 Nussbaum CE, Okawara SH, Jacobs LS. Lymphocytic hypophysitis with involvement of the cavernous sinus and hypothalamus. Neurosurgery 1991;28:440-4.

18 Hayashi H, Yamada K, Toshitaka K, et al. Lymphocytic hypophysitis and pulmonary sarcoidosis. Am f Clin Pathol 1;95:506-11.

19 Madsen FF, Dohr O, Ludwigsen E. Lymphocytic adenohypophysitis. A review and a case. Dan Med Bull 1985;23: $185-8$.

20 Vasikaran SD, Tallis GA, Braund WJ. Secondary hypoadrenalism presenting with hypercalcaemia. Clin Endocrinol 1994;41:261-4

21 Patel MC, Guneratne N, Haq N, et al. Peripartum hypopituitarism and lymphocytic hypophysitis. Qf Med 1995;88: 571-80.

22 Pholsena M, Young J, Couzinet B, et al. Primary adrenal and thyroid insufficiencies associated with hypopituitarism: a diagnostic challenge. Clin Endocrinol 1994;40:693-5.

23 Bitton RN, Slavin M, Decker RE, et al: The course of lymphocytic hypophysitis. Surg Neurol 1991;36:40-3.

24 Kanatani M, Nakamura R, Kurokawa K, et al. Hypopituitarism associated with Cogan's syndrome; high-dose glucocorticoid therapy reverses pituitary swelling. Case report. fpn f Med Sci Biol 1991;30:164-9.

25 Mayfield RK, Levine JH, Gordon L, et al. Lymphoid adenohypophysitis presenting as a pituitary tumor. $\mathrm{Am} 7 \mathrm{Med}$ 1980;69:619-23.

26 McDonald MA, Brophy BP, Raymond W. Lymphocytic hypophysitis: a rare cause of hyperprolactinaemia. Aust $N Z$ f Surg 1995;65:538-9.- 